\title{
Comparison of early surgical alternatives in the management of open abdomen: a randomized controlled study
}

\author{
Ahmet Rencüzoğulları, M.D., ${ }^{1}$ Kubilay Dalcı, M.D., ${ }^{1}$ İsmail Cem Eray, M.D., ${ }^{1}$ \\ Orçun Yalav, M.D., ${ }^{1}$ Alexis Kofi Okoh, M.D., ${ }^{2}$ Tolga Akcam, M.D., ${ }^{1}$ \\ Abdullah Ülkü, M.D., ${ }^{1}$ Gürhan Sakman, M.D., ${ }^{1}$ Cem P. Parsak, M.D. ${ }^{1}$
}

1Department of General Surgery, Çukurova University Faculty of Medicine, Adana

${ }^{2}$ Department of General Surgery, Ankara University Faculty of Medicine, Ankara

\begin{abstract}
BACKGROUND: Abdominal compartment syndrome (ACS) is a clinical syndrome characterized by progressive intraabdominal organ dysfunction resulting from an acute increase in intra-abdominal pressure (IAP). In the absence of prompt treatment, ACS can lead to lethal organ failure. Treatment of ACS is achieved by immediate decompression of the abdominal cavity. As to how and when decompression laparotomy should be performed depends on the clinical condition of the patients. There is limited data regarding outcomes of abdominal closure techiques. The present study aimed to investigate two different temporary closure methods, the vacuum assisted closure (VAC) and Bogota bag techniques, in 40 patients who underwent decompressive laparotomy as part of the management of ACS.
\end{abstract}

METHODS: The study included 40 patients who developed ACS during follow-up or following trauma and abdominal surgery. As part of the treatment for ACS, these patients underwent decompressive laparotomy at the Cukurova University Medical Faculty, General Surgery Department and followed up in the Intensive Care Unit of the same hospital. VAC and Bogota bag procedures were performed as temporary closure methods for the treatment of ACS. Patients were randomly assigned to each of the two groups according to the temporary closure method performed. Clinical, laboratory, mortality and morbidity results of the patients in both groups were compared.

RESULTS: Demographic features of the patients (age, sex, body mass index, co-morbidities) were similar between the two groups. The most common reason of ACS was gastrointestinal perforation in 12 (30\%) patients. Decrease in incision width was significantly faster in the VAC group than in the Bogota group. Primary closure of fascia was considered appropriate in I6.9 days in the VAC group and 20.5 days in the Bogota bag group. The decrease in abdominal pressure was similar between the two groups on days I, 4 and 7 but appeared to be significantly lower on day 14 in the VAC group. 12 patients (30\%) died during the study. Among the deceased patients, 5 (12\%) were in the VAC group, whereas, 7 (17.5\%) belonged to the Bogota bag group.

CONCLUSION: Based on these results, it is suggested that VAC has advantages when compared to the Bogota bag as a temporary closure method in the management of abdominal compartment syndrome.

Key words: Abdominal compartment syndrome; Bogota bag; intraabdominal hypertension; vacuum assisted closure.

\section{INTRODUCTION}

Abdominal compartment syndrome (ACS) is a clinical syn-

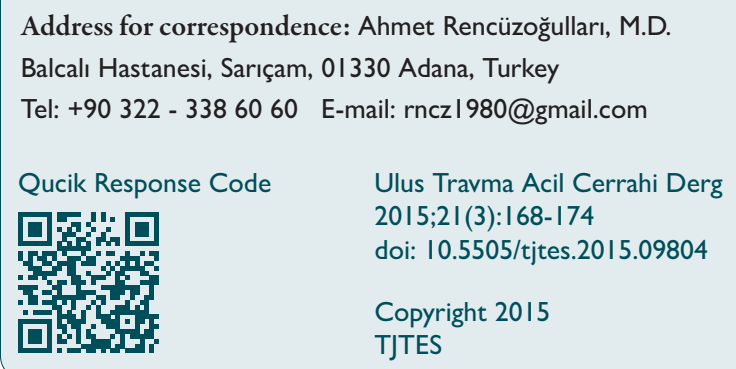

drome that occurs secondary to an acute increase in intraabdominal pressure (IAP) resulting in malfunctioning of respiratory, renal or cardiovascular organs. ${ }^{[1,2]}$ Major abdominal trauma, disseminated intra-abdominal infections and complicated or prolonged surgeries are among some of the clinical causes of ACS.

Laparostomy, often called as open abdomen, and temporary abdominal closure are life saving interventions in ACS, trauma and abdominal sepsis. ${ }^{[3-8]}$ Protein deficiency, hypothermia, massive fluid loss due to abdominal wall deficiency and contamination with exogenous bacteria are known to complicate the medical management of ACS. ${ }^{[8,9]}$ The main objective of open wound treatment is to save the integrity of the 
abdominal wall, banish the exudate, reduce fluid loss to the third spaces, control the infection and to avoid fistula formation. ${ }^{[9,10]}$ The optimum temporary closure technique should, therefore, provide these main goals without traumatizing intestinal organs.

Different choices of temporary abdominal closure with considerable advantages and disadvantages currently exist; however, a consensus on which technique should be the treatment of choice hasn't been reached yet. To the best of our knowledge, a prospective study comparing the advantages and disadvantages of different techniques is lacking in the current literature. In the current prospective randomized study, the results of two different temporary abdominal closure techniques, the vacuum assisted closure (VAC) and Bogota bag were compared.

\section{MATERIALS AND METHODS}

Between February 2007 and September 2010, forty patients, who developed ACS during follow-up or following trauma and abdominal surgery, underwent decompressive laparotomy as part of the treatment for ACS in the General Surgery Department of the Çukurova University Medical Faculty. Patients with grade III (2I-25 $\mathrm{mmHg})$ and IV $(>25 \mathrm{mmHg})$ IAP according to the World Society of Abdominal Compartment Syndrome (WSACS) grading system, patients who were under follow up in the surgical intensive care unit, and those who developed ACS as a result of progressively increasing IAP were included into the study. Patients with American Society of Anesthesologists score 5 exculed from the study.

Forty patients were prospectively randomized either into a VAC and Bogota group in which the open abdomen was managed with vacuum assisted closure or Bogota bag procedures.

The study group consisted of twenty-three males and seventeen females. The median age of the patients was 50.9 years. Clinical, laboratory, mortality and morbidity results of the patients in both groups were recorded and prospectively analyzed. Local ethical Committee approval for the study was received from Çukurova University, Medical Faculty. In order to prevent the development or deterioration of ACS, daily monitorization of IAP was carried out in patients with abdominal and pelvic trauma, head trauma with associated increased intracranial pressure, respiratory insufficiency requiring high pressure ventilation, complicated abdominal surgeries and those with major trauma requiring greater volumes of fluid resuscitation. So as to decrease the risk of developing ACS, fluid administration was limited in patients, and colloids were used under certain circumstances.

Nasogastric and rectal drainage were employed as intraabdominal pressure reducing measures in patients with bowel distention. All patients were placed in supine position to eliminate the effect of patient positioning on IAP measure- ments. Intraabdominal pressure was measured by using the bladder pressure measurement technique which was first described by Kron et al. and later confirmed by Obeid et al. With the patient in $180^{\circ}$ supine position, a drainage tube connected to the Foley catheter was clamped. $25 \mathrm{ml}$ of saline was instilled into the bladder via the aspiration port using an 18-gauge needle. The needle was attached to a three-way stopcock and water manometer. After saline injection, a wait time of 60 seconds was allowed for decontraction of the detrusor muscle. The zero mark of the manometer was placed at the level of the pubic symphysis, and the pressure was read at the meniscus at the end of expirium.

Since mechanical ventilation can act as a predisposing factor for elevated IAP, especially in scenarios where positive end respiratory pressure is applied, ventilation was ceased in patients on mechanical ventilation during IAP measurements to avoid false results. Vecuronium bromide $(0.1 \mathrm{mg} / \mathrm{kg})$ in intermittent dosing schedule was used for adequate muscular relaxation for two reasons: to eliminate spontaneous breathing and to decrease oxygen consumption.

IAP results, patient characteristics, co-morbidities and mortalities were recorded. VAC system consisted of a polyure-

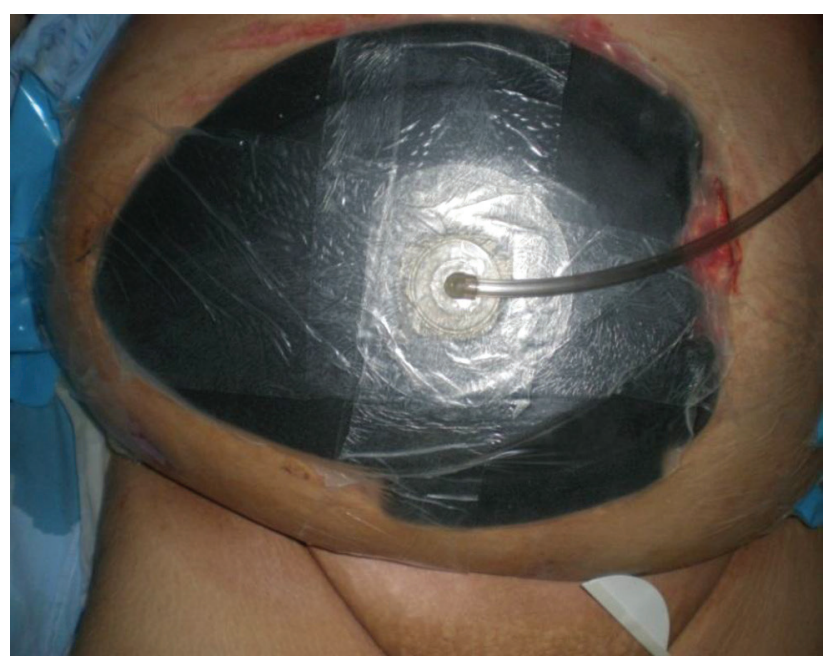

Figure 1. Vacuum assisted closure in a patient.

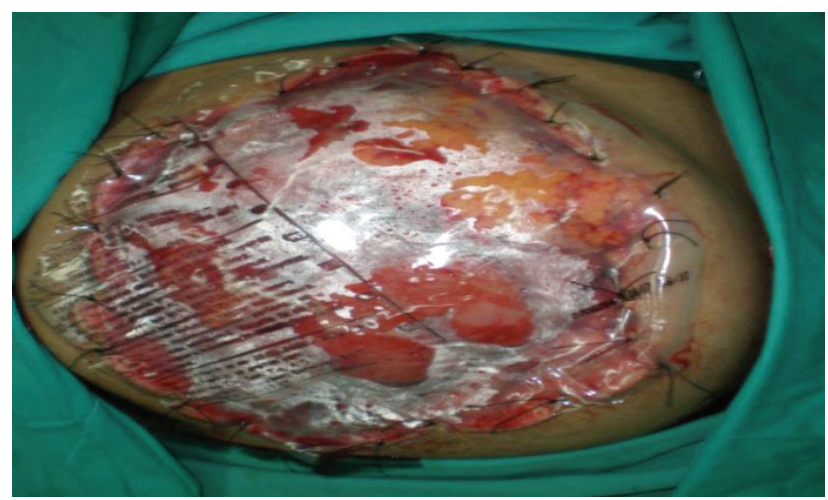

Figure 2. Bogota bag application in a patient. 
Table I. Patient demographics

\begin{tabular}{|c|c|c|c|c|c|c|c|c|}
\hline & \multicolumn{3}{|c|}{ Vacuum assisted closure } & \multicolumn{4}{|c|}{ Bogata bag } & \multirow[t]{2}{*}{$\mathbf{p}$} \\
\hline & $\mathbf{n}$ & $\%$ & Mean $\pm S D$ & $\mathbf{n}$ & $\%$ & Mean士SD & Median (Min.-Max.) & \\
\hline Male & II & 55.0 & & 12 & 60.0 & & & \\
\hline Female & 9 & 45.0 & & 8 & 40.0 & 0.749 & & \\
\hline Age & & & $52.3 \pm 15.9$ & & & $50.1 \pm 18.0$ & $49.5(24.0-81.0)$ & 0.678 \\
\hline Body mass index & & & $27.5 \pm 5.3$ & & & $27.1 \pm 5.0$ & $27.4(|8.7-4| .0)$ & 0.784 \\
\hline
\end{tabular}

thane sponge that was placed on the abdominal cavity with an I8-French sized vacuum tube. It was covered with a second layer of occlusive sterile coat. The system was settled after the vacuum tube was connected to a portable pump. The sterile coat was changed every 72 hours (Fig. I). The Bogota Bag technique was performed by fixing a sterile plastic bag onto the skin of abdomen (Fig. 2). The primary end points measured were pre and postoperative IAPs, width of incision, duration of wound healing, time of abdomen closure and discharge, mortalities and complications.

\section{Statistical Analysis}

Statistical analysis was performed using the Statistical Package for Social Sciences (SPSS version 17). Continuous variables were checked for normality by using the Kolmogorov Smirnov, Shapiro-Wilk tests and histograms. Comparisons between groups were made using the Student's t-test for normally distributed data. The Mann-Whitney U-test was used for data that were not normally distributed. Pre and post operative days were analyzed using the Reorat measure Analysis-Greenhouse-Geisser Test. Statistical significance was accepted for $p$ values less than 0.05 .

\section{RESULTS}

Forty patients with grade III and IV IAP and abdominal compartment syndrome were included into the study. Demographic characteristic of the patients are given in Table I. The

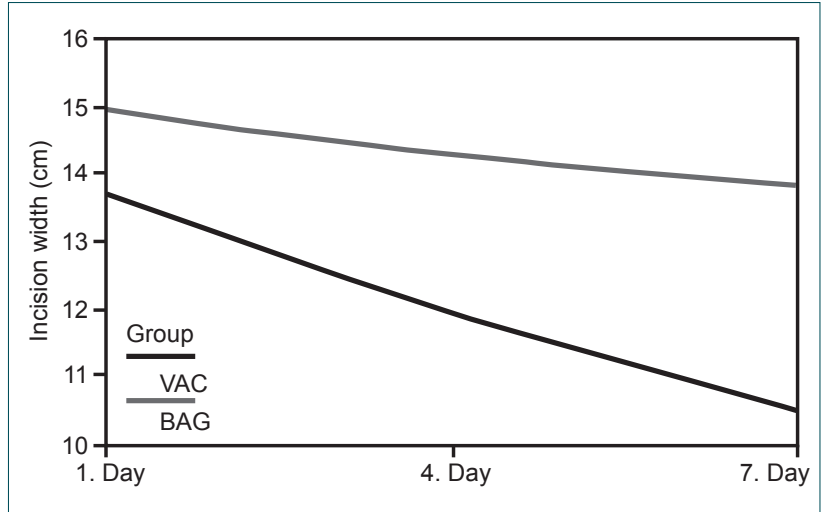

Figure 3. The reduction of the incision width by time in groups. most common etiology in ACS patients was gastrointestinal perforation that occurred in twelve $(30 \%)$ patients. Other etiological factors are shown in Table 2 . The mean time between admission of the patients and laparostomy was 3.9 93.2 $h$ in the VAC group and $5.7 \pm 4.9 h$ in the Bogota bag group $(p>0.05)$. Measurements of skin-to-skin width of incision were made; however, the results did not differ significantly between groups on day I (VAC: $13.8 \pm 3.2 \mathrm{~cm}$, Bag I5.0 \pm 3.8 , $\mathrm{p}=0.289$ ), but the width in the VAC group was reduced significantly on days 4 and 7 (Table 3, Fig. 3).

Mean IAP was $21.1 \pm 4.3 \mathrm{mmHg}$ before laparostomy in the VAC group and $21.6 \pm 4.1 \mathrm{mmHg}$ in the Bogota bag group ( $>0.05)$. Mean IAP on day I, 4, 7 and I4 was $7.6 \pm 2.9 \mathrm{~mm}-\mathrm{hg}, 6.3 \pm 2.7$ $\mathrm{mm}-\mathrm{hg}, 5.2 \pm 2.9 \mathrm{mmHg}$, and $3.5 \pm 1.6 \mathrm{mmHg}$ in the VAC group,

Table 2. Etiology of abdominal compartment syndrome

\begin{tabular}{lcc}
\hline Primer etiology & n & $\%$ \\
\hline Gastrointestinal perforation & 12 & 30.0 \\
Pancreatitis & 9 & 22.5 \\
Ileus & 3 & 7.5 \\
Major Trauma & 7 & 17.5 \\
Malignancy & 9 & 2.5 \\
Total & 40 & 100.0 \\
\hline
\end{tabular}

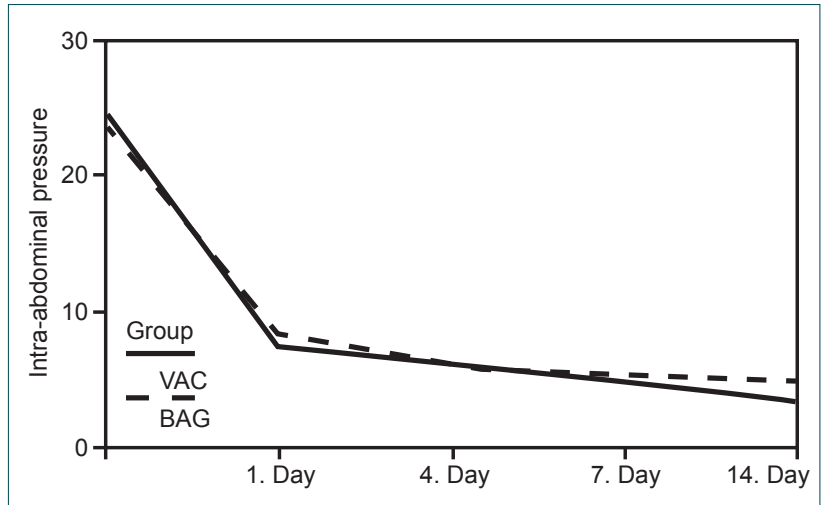

Figure 4. Postoperative intra-abdominal pressure changes in groups. 
Table 3. Skin to skin width of incisions on different days

\begin{tabular}{|c|c|c|c|c|c|c|}
\hline & \multicolumn{2}{|c|}{ Vacuum assisted closure } & \multicolumn{2}{|c|}{ Bogata bag } & \multirow[t]{2}{*}{$\mathbf{p}$} & \multirow[t]{2}{*}{$\mathbf{p}^{*}$} \\
\hline & Mean $\pm S D$ & Median (Min.-Max.) & Mean士SD & Median (Min.-Max.) & & \\
\hline Day 0I & $13.8 \pm 3.2$ & I $3.0(9.0-23.0)$ & $15.0 \pm 3.8$ & I $5.5(7.0-25.0)$ & 0.289 & \\
\hline Day 04 & $11.9 \pm 2.7$ & II $.5(8.0-2.0)$ & $14.3 \pm 3.8$ & $15.0(5.0-24.0)$ & 0.029 & \\
\hline Day 07 & $10.5 \pm 2.4$ & $10.0(7.0-18.0)$ & $13.9 \pm 3.8$ & I $4.5(5.0-24.0)$ & 0.002 & 0.0001 \\
\hline
\end{tabular}

Table 4. IAP on different days

\begin{tabular}{|c|c|c|c|c|c|c|}
\hline & \multicolumn{2}{|c|}{ Vacuum assisted closure } & \multicolumn{2}{|c|}{ Bogata bag } & \multirow[t]{2}{*}{$\mathbf{p}$} & \multirow[t]{2}{*}{$\mathbf{p}^{*}$} \\
\hline & Mean $\pm S D$ & Median (Min.-Max.) & Mean \pm SD & Median (Min.-Max.) & & \\
\hline Day 0I & $7.6 \pm 2.9$ & $7.0(4.0-16.0)$ & $8.4 \pm 3.4$ & $8.0(3.0-15.0)$ & 0.460 & \\
\hline Day 04 & $6.3 \pm 2.7$ & $6.0(2.0-15.0)$ & $6.3 \pm 3.4$ & $6.5(2.0-13.0)$ & 0.959 & \\
\hline Day 07 & $5.2 \pm 2.9$ & $4.0(2.0-13.0)$ & $5.6 \pm 2.9$ & $5.0(1.0-11.0)$ & 0.705 & \\
\hline Day 14 & $3.5 \pm 1.6$ & $3.0(1.0-8.0)$ & $5.1 \pm 2.5$ & $4.5(0.0-10.0)$ & 0.026 & 0.160 \\
\hline
\end{tabular}

p: Mann Whitney Test; p*: Repeated Measures Analyses -Greenhouse-Geisser test.

Table 5. Complications seen in both groups

\begin{tabular}{lcccc}
\hline Complication & Vacuum assisted closure & Bogata bag & $\mathbf{n}$ & $\%$ \\
\hline Acute renal failure & 4 & 5 & 9 & 22.5 \\
Sepsis & 2 & 4 & 6 & 15.0 \\
Pneumonia & 3 & 3 & 6 & 15.0 \\
Myocardial infarction & 1 & - & 1 & 2.5 \\
Fistula & 2 & 1 & 3 & 7.5 \\
Pulmonary emboli & - & & 1 & 2.5 \\
Absent & & & 14 & 35.0 \\
Total & & 40 & 100.0 \\
\hline
\end{tabular}

respectively. In the Bogota group, mean IAPs were $8.4 \pm 3.4$ $\mathrm{mmHg}, 6.3 \pm 3.4 \mathrm{mmHg}, 5.6 \pm 2.9 \mathrm{mmHg}$, and $5.1 \pm 2.5 \mathrm{mmHg}$, respectively (Table 4). Mean values were not significantly different on days I, 4, and 7, but on day I4, the IAP was significantly lower in the VAC group (Table 4, Fig. 4).

Mean time for wound closure was $16.9 \pm 3.2$ days in the VAC group and 20.5 \pm 9.9 days in the Bogota bag group $(p=0.003)$. Mean intensive care unit stay was similar in both groups (VAC: $33.9 \pm 15.2$ days; Bogota bag: $31.3 \pm 20.0$ days; $p=0.640$ ). Mean time for patient discharge was similar in both groups (28.5 \pm 21.3 days in the VAC group; $27.4 \pm 25.3$ days in the Bogota bag group).

During clinical follow up, complications were observed in eleven patients (55\%) from the VAC group and in fifteen $(75 \%)$ patients in the Bogota bag group ( $p>0.05)$. The most common complication was acute renal failure, which was seen in nine patients. Other developing complications and their distribution among the groups are shown in Table 5. There were no statistically significant relationships between complications seen in both groups. There were no complications in fourteen patients. Five patients died in the VAC group and seven patients died in the Bogota Bag group, but the difference was not statistically significant.

\section{DISCUSSION}

Temporary abdomen closure in the management of open abdomen is not standardized and depends solely on the discretion and experience of the attending surgeon. However, in 
patients who develop ACS with grade III and IV IAP, the need for temporary abdomen closure as part of the management of open abdomen is clear.

In the current, prospective, randomized study, the results of two different temporary abdominal closure techniques, VAC and Bogota bag in ACS patients were compared and it was found that the width of incision decreased significantly faster in the VAC group. Moreover, IAP was significantly lower on day 14 in the VAC group with faster wound closure and no increase in complication and mortality.

The most common reason for high intra-abdominal pressure is the increase in the intraperitoneal fluid volume. Pancreatitis, blood loss, edema and secondary increase in the retroperitoneal volume can cause ACS. ${ }^{[1-13]}$ Meldrum et al. have reported that ACS occurred in twenty-one of one hundred and fortyfive patients $(14 \%)$ with serious abdominal trauma ${ }^{[14]}$ and that the most common cause was intra-abdominal bleeding due to liver injury in $57 \%$ of the cases. Morris et al. have observed one hundred and seven patients with serious abdominal trauma and declared that ACS occurred in sixteen (15\%) patients. In the present study including forty patients, the most common reason for ACS was gastrointestinal perforation in twelve patients. Trauma was the etiology in seven patients. ${ }^{[15]}$

Measurement of bladder pressure which was first described by Kron et al. ${ }^{[16]}$ and confirmed by Obeid et al. ${ }^{[17]}$ has been shown to be the most reliable method of measuring IAP. In their study, they have measured the IAP directly via an intraperitoneal catheter from the bladder, stomach or rectum. They have also compared the changes in position and concluded that the IAP results measured from the bladder are the most reliable and that the other three ways are not reliable when the positions changed. Our study adopted the bladder catheter method as described above for the measurements of IAP.

ACS is becoming a more common problem in modern trauma centers. ${ }^{[18,19]}$ Temporary abdominal closure techniques are used in the management of this situation, but some authors have suggested utilization of different techniques. To date, a consensus on which treatment method should be used has not been reached yet, ${ }^{[20-23]}$ and to the best of our knowledge this is the first prospective, randomized study comparing the results of these techniques.

The optimum temporary closure technique should prevent intestinal adhesion, protect the skin and allow a close observation of the abdominal cavity. ${ }^{[22-25]}$ The main advantages of the Bogota bag are that it is cheap, easily performed and replaceable. In addition, the volume loss can be reduced to minimum, and muscular necrosis can be avoided, infection can be drained and inspection is easily done. ${ }^{[26,27]}$ Current VAC systems have advantages like reduced escape, easy manipulation and control of the fistula. In most series, VAC allows primary abdominal closure without causing ventral hernia. ${ }^{[28]}$ It is also skin protective. However, the major disadvantage of the VAC technique is its high cost. The most common complications in patients treated with VAC are fistula and abdominal compartment syndrome. ${ }^{[29-31]}$ In our study, none of the patients in both groups had reoccurred ACS; however the most common complication was acute renal failure. Fistula developed in two (5\%) patients in the VAC group and in one $(2.5 \%)$ patient in the bag group.

Batacchi et al. have compared abdominal closure time using the VAC and Bogota bag techniques and reported that abdominal closure could be achieved earlier in the VAC group. ${ }^{[32]}$ Similarly, the present study revealed a significantly earlier abdominal closure time in the VAC group. Recently, a study by Long and colleagues has evaluated the utility of concomitant therapies for open abdomen by comparing the VAC used in combination with the abdominal re-approximation abdominal wall anchor closure (ABRA) system for closure of open abdomen. Primary closure rates between the groups were not statistically significant; however, their study reported fewer operating room visits and time use in patients treated with both systems. ${ }^{[33]}$

Despite recent developments in surgery, mortality among patients with ACS still remains high with a reported range between $42 \%$ and $71 \%,{ }^{[34]}$ which is probably due to co-morbidities. In our study, five patients in the VAC group and seven patients in the bag group died. ( 12 in total, 30\%). Mortality in ACS is still the most important problem in the early period of ACS. Parsak et al. have declared that intra-abdominal hypertension is directly correlated with mortality in ACS, but that it is not the only factor. ${ }^{[35]}$ They have found that mortality is highest during the first three days and suggested that the IAP should be decreased under a cut off level in the first three days. In the present study, the IAP levels were similar in the two groups on days I, 4, 7 and so were mortality rates. Yet, IAP was significantly lower in the VAC group on day I4, which could be one of the reasons for earlier abdominal closure in this group.

This study offers a closer look at the potential benefits VAC may have over the Bogota bag as a temporary closure technique in the management of abdominal compartment syndrome. The need for larger prospective studies comparing current methods for abdominal closure should be addressed especially in this era where multiple options and increasing operative interventions have been developed for the treatment of critically ill patients.

Conflict of interest: None declared.

\section{REFERENCES}

1. Schein M, Wittmann DH, Aprahamian CC, Condon RE. The abdomi- 
nal compartment syndrome: the physiological and clinical consequences of elevated intra-abdominal pressure. J Am Coll Surg 1995;180:745-53.

2. Nathens AB, Boulanger BR. The abdominal compartment syndrome. Curr Opin Crit Care 1998;4:116-20. CrossRef

3. Iberti TJ, Kelly KM, Gentili DR, Hirsch S, Benjamin E. A simple technique to accurately determine intra-abdominal pressure. Crit Care Med. 1987; 15:1140-2. CrossRef

4. Eddy V, Nunn C, Morris JA Jr. Abdominal compartment syndrome. The Nashville experience. Surg Clin North Am 1997;77:801-12. CrossRef

5. Mayberry JC, Mullins RJ, Crass RA, Trunkey DD. Prevention of abdominal compartment syndrome by absorbable mesh prosthesis closure. Arch Surg 1997;132:957-62. CrossRef

6. Boffard K. Abdominal trauma. In: Patterson- Brown S, editor. Core topics in general and emergency surgery, 2nd edn. Edinburgh: Saunders 2001;305-52.

7. Malbrain ML. Is it wise not to think about intraabdominal hypertension in the ICU? Curr Opin Crit Care 2004;10:132-45. CrossRef

8. Brooks A, Mahoney P, Schwab CW. Critical care of the trauma patient. In: Brooks A, Girling K, RileyB, RowlandsB, editors. Critical care for postgraduate trainees. London: Hodder Arnold 2005;119-20.

9. Schecter WP, Ivatury RR, Rotondo MF, Hirshberg A. Open abdomen after trauma and abdominal sepsis: a strategy for management. J Am Coll Surg 2006;203:390-6. CrossRef

10. Deenichin GP. Abdominal compartment syndrome. Surg Today 2008;38:5-19. CrossRef

11. Schein M, Wittman DH, The abdominal comparment syndrome following peritonitis, abdominal trauma and operations. Complications in Surgery 1996;15:1-10.

12. Hamzaoğlu İ, Erdoğan K, Yiğitbaşı R, Abdominal kompartman sendromu. Aktüel Tip Dergisi 1999;4:259-62.

13. Saggi BH, Sugerman HJ, Ivatury RR, Bloomfield GL. Abdominal compartment syndrome. J Trauma 1998;45:597-609. CrossRef

14. Meldrum DR, Moore FA, Moore EE, Franciose RJ, Sauaia A, Burch JM. Prospective characterization and selective management of the abdominal compartment syndrome. Am J Surg 1997;174:667-73. CrossRef

15. Morris JA Jr, Eddy VA, Blinman TA, Rutherford EJ, Sharp KW. The staged celiotomy for trauma. Issues in unpacking and reconstruction. Ann Surg 1993;217:576-86. CrossRef

16. Kron IL, Harman PK, Nolan SP. The measurement of intra-abdominal pressure as a criterion for abdominal re-exploration. Ann Surg 1984;199:28-30. CrossRef

17. Obeid F, Saba A, Fath J, Guslits B, Chung R, Sorensen V, et al. Increases in intra-abdominal pressure affect pulmonary compliance. Arch Surg 1995;130:544-8. CrossRef

18. Losanoff JE, Richman BW, Jones JW. Temporary abdominal coverage and reclosure of the open abdomen: frequently asked questions. J Am Coll Surg 2002;195:105-15. CrossRef

19. Vertrees A, Kellicut D, Ottman S, Peoples G, Shriver C. Early definitive abdominal closure using serial closure technique on injured soldiers returning from Afghanistan and Iraq. J Am Coll Surg 2006;202:76272. CrossRef

20. Navsaria PH, Bunting M, Omoshoro-Jones J, Nicol AJ, Kahn D. Temporary closure of open abdominal wounds by the modified sandwichvacuum pack technique. Br J Surg 2003;90:718-22. CrossRef

21. Howdieshell TR, Proctor CD, Sternberg E, Cué JI, Mondy JS, Hawkins ML. Temporary abdominal closure followed by definitive abdominal wall reconstruction of the open abdomen. Am J Surg 2004;188:301-6. CrossRef

22. Rutherford EJ, Skeete DA, Brasel KJ. Management of the patient with an open abdomen: techniques in temporary and definitive closure. Curr Probl Surg 2004;41:815-76. CrossRef

23. Hutchins RR, Gunning MP, Lucas DN, Allen-Mersh TG, Soni NC. Relaparotomy for suspected intraperitoneal sepsis after abdominal surgery. World J Surg 2004;28:137-41. CrossRef

24. Labler L, Zwingmann J, Mayer D, Stocker R, Trentz O, Keel M. V.A.C.İ abdominal dressing system. Eur J Traum 2005;31:488-94. CrossRef

25. Barker DE, Kaufman HJ, Smith LA, Ciraulo DL, Richart CL, Burns RP. Vacuum pack technique of temporary abdominal closure: a 7-year experience with 112 patients. J Trauma 2000;48:201-7. CrossRef

26. Townsend C, Beauchamp RD, Evers M. Sabiston textbook of surgery. 17th ed; Philadelphia, PA: Elsevier Saunders 2004.

27. Stonerock CE, Bynoe RP, Yost MJ, Nottingham JM. Use of a vacuumassisted device to facilitate abdominal closure. Am Surg 2003;69:1030-5.

28. Fansler RF, Taheri P, Cullinane C, Sabates B, Flint LM. Polypropylene mesh closure of the complicated abdominal wound. Am J Surg 1995; 170:15-8. CrossRef

29. Benninger E, Labler L, Seifert B, Trentz O, Menger MD, Meier C. In vitro comparison of intra-abdominal hypertension development after different temporary abdominal closure techniques. J Surg Res 2008;144:102-6.

30. Collicott PE, Hughes I. Training in advanced trauma life support. JAMA 1980;243:1156-9. CrossRef

31. Rutherford EJ, Skeete DA, Brasel KJ. Management of the patient with an open abdomen: techniques in temporary and definitive closure. Curr Probl Surg 2004;41:815-76. CrossRef

32. Batacchi S, Matano S, Nella A, Zagli G, Bonizzoli M, Pasquini A, et al. Vacuum-assisted closure device enhances recovery of critically ill patients following emergency surgical procedures. Crit Care 2009;13:R194. CrossRef

33. Long KL, Hamilton DA, Davenport DL, Bernard AC, Kearney PA, Chang PK. A prospective, controlled evaluation of the abdominal reapproximation anchor abdominal wall closure system in combination with VAC therapy compared with VAC alone in the management of an open abdomen. Am Surg 2014;80:567-71.

34. Lacey SR, Bruce J, Brooks SP, Griswald J, Ferguson W, Allen JE, et al. The relative merits of various methods of indirect measurement of intraabdominal pressure as a guide to closure of abdominal wall defects. J Pediatr Surg 1987;22:1207-11. CrossRef

35. Parsak CK, Seydaoglu G, Sakman G, Acarturk TO, Karakoc E, Hanta I, et al. Abdominal compartment syndrome: current problems and new strategies. World J Surg 2008;32:13-9. CrossRef 
ORİJINAL ÇALIŞMA - ÖZET

\title{
Open abdomen yönetiminde erken dönem cerrahi alternatiflerin karşılaştırılması: Randomize ileriye yönelik çalışma
}

\author{
Dr. Ahmet Rencüzoğulları, ${ }^{1}$ Dr. Kubilay Dalcı, ${ }^{1}$ Dr. İsmail Cem Eray, ${ }^{1}$ Dr. Orçun Yalav, ${ }^{1}$ \\ Dr. Alexis Kofi Okoh, ${ }^{2}$ Dr. Tolga Akçam, ${ }^{1}$ Dr. Abdullah Ülkü, ${ }^{1}$ Dr. Gürhan Sakman, ${ }^{1}$ Dr. Cem P. Parsak ${ }^{1}$
}

${ }^{1}$ Çukurova Üniversitesi Tıp Fakültesi, Genel Cerrahi Anabilim Dalı, Adana ${ }^{2}$ Ankara Üniversitesi Tıp Fakültesi, Genel Cerrahi Anabilim Dalı, Ankara

AMAÇ: Abdominal kompartman sendromu (AKS), sınırlı bir anatomik alana sahip karında basıncın akut ve patolojik artışı ile karakterize olup, tedavi edilmediği takdirde yüksek oranda mortaliteyle sonuçlananan klinik bir durumdur. Karıniçi basıncın progresif yükselmesi sonucu ortaya çıkan bu sendromun etkileri sistemik olarak ortaya çıkar. Abdominal kompartman sendromunun tedavisi, artmış karıniçi basıncın düşürülmesidir. Dekompresif laparotomi kararını vermede en önemli kriter hastanın klinik tablosudur. Grade 3 ve 4 hastalarda dekompresif laparatomiyi takiben ameliyat sonrası karıniçi basının tekrar yükselmesini engellemek için karın kapatılmaz, açık abdomen uygulanır. Bu çalışmada, dekompresif laparotomi uygulanmış evre 3 ve 4 AKS'li hastalara geçici karın kapatılmasında kullanılan Vacuum-assisted closure (VAC) ve Bogota bag yöntemlerinin randomize ileriye yönelik değerlendirilmesi amaçlandı.

GEREÇ VE YÖNTEM: Bu çalışmaya Şubat 2007 ile Eylül 2010 tarihleri arasında Çukurova Üniversitesi Tıp Fakültesi Genel Cerrahi Yoğun Bakımı’na travma, geçirilmiş cerrahi sonrası ya da medikal takiplerinin izlemi sırasında AKS gelişmiş ve tedavilerinin bir parçası olarak dekompresif laparotomi uygulanmış 40 hasta alındı. Hastalar ardışık randomizasyon yöntemi ile VAC ve Bogota bag olmak üzere iki gruba ayrıldı. Geçici karın kapama yöntemleri olan bu yöntemlerin sonuçları gruplar arasında randomize ileriye yönelik olarak klinik, laboratuvar, morbidite ve mortalite yönünden karşılaştırılarak değerlendirilldi.

BULGULAR: Her iki gruptaki hastaların yaş, cinsiyet, vücut kitle indeksi ve yandaş hastalıkları gibi demografik özellikleri arasında anlamlı fark yoktu. AKS gelişen hastalarda etiyolojik faktörler arasında en sık neden 12 hastada (\%30) görülen gastrointestinal sistem perforasyonu idi. İnsizyon boyutu ölçümlerinde VAC grubunda daha anlamlı bir azalma vardı. Hastanın primer fasya kapatılması için uygun hale gelmesi için geçen zaman VAC grubunda 16.9 gün iken, Bogota bag'li grupta 20.5 gün idi. Karıniçi basıncı düşürme değerlendirildiğinde; her iki grupta I., 4. ve 7. günlerde benzer oranlarda düşme saptanırken, ameliyat sonrası I4. günde VAC grubunda anlamlı olarak daha fazla düşme saptandı. Mortalite gelişen hasta sayısı I2 (\%30) iken, beş (\% 12.5) hasta VAC grubuna, yedi (\% 17.5) hasta Bogota bag grubuna aitti.

TARTIŞMA: Bulgulara dayanarak geçici karın kapama yöntemi olarak VAC uygulamasııın daha uygun olduğu kanaatindeyiz.

Anahtar sözcükler: Abdominal kompartman sendromu; Bogota bag; karıniçi hipertansiyon; randomize klinik çalısma; Vacuum assisted closure.

Ulus Travma Acil Cerrahi Derg 2015;2I(3):168-174 doi: 10.5505/tjtes.2015.09804 